\title{
Pengaruh Konsumsi Buah jeruk (Citrus reticulata) dan Suplementasi Zinc terhadap Kadar Glukosa Darah Puasa pada Wanita Diabetes Melitus Tipe 2
}

\section{Effect of Oranges (Citrus Reticulata) and Zinc Supplements Consumption on Fasting Blood Glucose in Women with Diabetes Mellitus Type 2}

Amalia Purwandari $1^{*}$, JB Suparyatmo ${ }^{1}$, Sugiarto ${ }^{1}$

\begin{abstract}
ABSTRAK
Latar Belakang : Pasien Diabetes Melitus (DM) Tipe 2 beresiko kehilangan zat gizi mikro terkait metabolik penyakitnya, salah satunya adalah zinc. Zinc berperan penting karena mempengaruhi fungsi sel $\beta$ pankreas, aktifitas insulin, homeostasis glukosa dan patogenesis DM. Kadar zinc yang rendah terkait dengan komplikasi DM yang lebih tinggi. Salah satu zat gizi yang membantu penyerapan zinc adalah asam organik seperti asam sitrat dan asam askorbat yang terkandung dalam buah jeruk.

Tujuan : Menganalisis pengaruh konsumsi buah jeruk (Citrus reticulata) dan suplementasi zinc terhadap kadar glukosa darah puasa wanita DM tipe 2.

Metode : Penelitian eksperimental dengan metode pretest and posttest with control group. Jumlah subjek 30 orang wanita DM tipe 2 anggota klub Prolanis di 3 Puskesmas di Kota Surabaya yang dipilih secara consecutive sampling, terbagi dalam 2 kelompok yaitu kelompok perlakuan yang mengkonsumsi 200 gram jeruk dan suplementasi zinc $20 \mathrm{mg} / \mathrm{hari}$ serta kelompok kontrol hanya mengkonsumsi zinc $20 \mathrm{mg} /$ hari. Buah jeruk dan suplemen zinc dikonsumsi setiap hari selama 4 minggu. Glukosa darah puasa dianalisa menggunakan automatic chemistry analizer. Analisis data meliputi univariat dengan ShapiroWilk, analisa bivariat meliputi Independent t-test dan Mann-Whitney serta Paired t-test.

Hasil : Kadar glukosa darah puasa pada subjek yang mengkonsumsi buah jeruk dan suplementasi zinc turun sebesar 16,67 $\mathrm{mg} / \mathrm{dl}$ (dari 155,87 mg/dl menjadi $139,20 \mathrm{mg} / \mathrm{dl})(\mathrm{p}=0,121)$, sedangkan pada kelompok yang mengkonsumsi zinc turun sebesar $9,85 \mathrm{mg} / \mathrm{dl}$ (dari 140,93 mg/dl menjadi 131,13 mg/dl) $(p=0,095)$. Penurunan kadar glukosa darah puasa pada kedua kelompok tersebut tidak signifikan secara statistik.

Kesimpulan : Konsumsi buah jeruk dan suplementasi zinc tidak signifikan menurunkan glukosa darah puasa wanita DM Tipe 2. Diperlukan penelitian lanjutan dengan jangka waktu intervensi yang lebih lama, agar lebih menggambarkan perubahan metabolisme zinc terkait kontrol glukosa darah.
\end{abstract}

Kata Kunci : diabetes melitus, jeruk, suplementasi zinc.

\section{ABSTRACT}

Background: Patients with Diabetes Mellitus (DM) Type 2 are at risk of micronutrient loss related to metabolic diseases, one of them is zinc. It plays an important role since it affects the function of pancreatic cell 6 , insulin activities, glucose homeostasis and pathogenesis of DM. Low zinc levels are associated with higher complications of DM. One of the nutrients that helps absorbing zinc is organic acids such as citric acid and ascorbic acid contained in citrus fruits.

Objective: to analyze the effect of citrus fruits (Citrus reticulata) and zinc supplements consumption on fasting blood glucose in women with DM Type 2.

Method: This study was an experimental study using pretest and posttest method with control group. The subjects were 30 people with DM Type 2 in Prolanis club in three Puskesmas in Surabaya who had been selected using consecutive sampling, and divided into 2 groups, namely the treatment group that consumed $200 \mathrm{~g}$ of orange and $20 \mathrm{mg}$ of zinc supplement per day and the control group that consumed only $20 \mathrm{mg}$ zinc per day. Citrus fruits and zinc supplements were consumed daily for four weeks. Fasting blood glucose was analyzed using automatic chemistry analyzer. Data analysis included univariate analysis with Shapiro-Wilk and bivariate analysis with Independent t-test, Mann-Whitney and Paired t-test

Results: Fasting blood glucose in the subjects consuming citrus fruits and zinc supplements was decreased by $16.67 \mathrm{mg} / \mathrm{dl}$ (from $155.87 \mathrm{mg} / \mathrm{dl}$ to $139.20 \mathrm{mg} / \mathrm{dl}$ ) $(p=0.121)$, while the group with zinc consumption was decreased by $9.85 \mathrm{mg} / \mathrm{dl}$ (from $140.93 \mathrm{mg} / \mathrm{dl}$ to $131.13 \mathrm{mg} / \mathrm{dl})(p=0.095)$. The decrease in fasting blood glucose in both groups was not statistically significant.

(C2019. Purwandari, dkk. Open access under CC BY - SA license.

Received: 11-07-2019, Accepted: 19-08-2019, Published online: 27-12-2019.

doi: 10.20473/amnt.v3.i4.2019.225-231, Joinly Published by IAGIKMI \& Universitas Airlangga 
Conclusion: Consumption of citrus fruits and zinc supplements did not significantly reduce fasting blood glucose in women with DM Type 2. Further research is needed with a longer period of intervention to better reflect the changes in zinc metabolism related to blood glucose control.

Keywords: diabetes mellitus, orange, zinc supplementation

\author{
*Koresponden: \\ amalia.purwandari@gmail.com \\ Amalia Purwandari \\ ${ }^{1}$ Universitas Sebelas Maret, Surakarta
}

\section{PENDAHULUAN}

IDF (International Diabetes Federation) memperkirakan bahwa penyandang Diabetes Melitus (DM) di seluruh dunia mengalami kenaikan dari 424 juta (tahun 2017) menjadi sekitar 628,6 juta jiwa (tahun 2045) dan Indonesia berada diurutan ke 6 dengan jumlah pasien DM 10,3 juta pada tahun $2017^{1}$. Data Riset Kesehatan Dasar menunjukkan penyandang diabetes usia $>15$ tahun di Jawa Timur masih diatas angka nasional ${ }^{2}$. Sebagian besar penyandang DM merupakan DM tipe $2^{3}$, atau disebut juga NIDDM (noninsulin-dependent DM) disebabkan karena penggunaan insulin yang kurang efektif dalam tubuh (resistensi insulin) terjadi pada $90-95 \%$ dari kasus diabetes ${ }^{4}$.

Beberapa penelitian menunjukkan bahwa zinc mempunyai pengaruh yang menguntungkan pada diabetes tipe 1 dan 2. Zinc memainkan peran penting pada fungsi sel $\beta$, aksi insulin, homeostasis glukosa dan patogenesis diabetes dan komplikasinya ${ }^{5}$. Peran spesifik zinc pada sel $\beta$ pankreas melalui sintesis, penyimpanan dan sekresi insulin. Homeostasis intraseluler zinc dikendalikan secara ketat oleh zinc transporters ( $Z n T$ dan Zip families) dan metallothioniens (MT) yang mengatur pengambilan, penyimpanan dan distribusi zinc. Peranan transporter zinc yang lain pada fungsi sel $\beta$ memungkinkan konstribusinya pada tatalaksana hiperglikemi pada pasien diabetes ${ }^{6}$. Konsentrasi zinc secara signifikan lebih rendah pada pasien diabetes dibanding dengan non diabetes ${ }^{7}$. Pasien DM Tipe2 memiliki kadar zinc yang lebih rendah dan hal ini terkait dengan tingginya komplikasi mikrovaskular diabetes ${ }^{8}$.

Faktor faktor yang mempengaruhi penyerapan zinc pada jaringan tubuh adalah jumlah dan bentuk zinc yang dikonsumsi, promotor diet seperti protein hewani dan senyawa organik dengan berat molekul rendah serta inhibitor makanan seperti fitat, suplemen kalsium dan Fe serta kondisi patologis khusus seperti hamil dan menyusui ${ }^{9}$. Menurut Silva dan Bracarense, penghambatan penyerapan logam di usus dapat dinetralkan oleh banyak senyawa dalam makanan seperti asam organik, asam askorbat, ligan kompleks, dan produk makanan fermentasi yang bersaing dengan fitat dalam mengikat mineral dan trace elemen. ${ }^{10}$ Beberapa upaya untuk meningkatkan penyerapan zinc dari makanan yaitu memasukkan berbagai bentuk tambahan pada zinc. Penambahan ligan makanan yang meningkatkan kelarutan zinc dapat meminimalkan interaksi antara zinc dan zat besi. Campuran fortifikasi zinc metionin, asam askorbat, asam sitrat tanpa kalsium fosfat dapat meningkatkan penyerapan zinc dan zat besi dari produk makanan ${ }^{11}$.

Jeruk merupakan sumber alami asam sitrat ${ }^{12}$. Buah jeruk merupakan buah yang banyak dikonsumsi setelah mangga, tomat dan pisang. Buah jeruk mengandung vitamin (antara lain vitamin C/asam askorbat), mineral, serat makanan dan pektin. Selain itu juga mengandung zat bioaktif seperti fenolik (flavanon, flavones, flavonol dan asam fenolik). Flavanon pada jeruk adalah hisperedin, eriocitrin naringin ${ }^{13}$. Hisperedin terbukti dapat menurunkan gula darah, serta meningkatkan plasma insulin dan glikogen tikus yang diinduksi streptozotozin ${ }^{14}$. Pektin pada jeruk dapat mempengaruhi glukosa darah puasa, mengurangi resistensi insulin, meningkatkan toleransi glukosa dan kadar glikogen hati pada tikus $\mathrm{DM}^{15}$.

Fortifikasi atau suplementasi zinc diperlukan jika rasio fitat dan zinc tidak dapat dikurangi dengan modifikasi diet, seperti penambahan sumber zinc hewani, pengurangan fitat dengan fermentasi atau keduanya ${ }^{16}$. Efisiensi penyerapan zinc dari suplemen jauh lebih tinggi daripada dari makanan, bahkan tanpa adanya inhibitor penyerapan zinc dalam makanan ${ }^{17}$.

Penelitian bertujuan untuk menganalisis pengaruh konsumsi jeruk (Citrus reticulata) dan suplementasi zinc terhadap glukosa darah puasa wanita Diabetes Melitus tipe 2. Jeruk merupakan buah yang banyak dikonsumsi masyarakat, mudah didapat dan harganya terjangkau, buah jeruk juga mengandung asam organik (asam sitrat) yang lebih tinggi dibandingkan dengan buah lain. Penulis berharap hasil penelitian akan menambah pengetahuan masyarakat, khususnya penyandang DM tipe 2 tentang manfaat mengkonsumsi buah jeruk yang merupakan sumber asam sitrat untuk membantu penyerapan zinc dari makanan dan suplemen sehingga kadar glukosa darah dapat dikendalikan, dan dapat mencegah komplikasi lebih lanjut.

\section{METODE}

Jenis Penelitian

Jenis penelitian adalah penelitian eksperimental dan metode pretest and posttest dan dengan grup kontrol. Subjek penelitian diambil dari populasi pasien Diabetes Melitus tipe 2 dan tergabung dalam klub Prolanis (Pengelolaan Penyakit Kronis) pada 3 Puskesmas di Kota Surabaya yaitu Puskesmas Kalijudan, Rangkah dan Pacarkeling. 


\section{Sampel dan Subjek penelitian}

Sampel penelitian ditentukan dengan cara consequtive sampling yaitu berdasarkan kriteria inklusi dan kriterian eksklusi. Inklusi meliputi, wanita usia 40-60 tahun, menggunakan terapi oral diabetes, tidak merokok, tidak mengkonsumsi suplementasi besi, kalsium dan vitamin C. Eksklusi jika subjek hamil, mendapat terapi insulin serta mempunyai komplikasi penyakit ginjal, jantung, hepar dan stroke. Penelitian menggunakan 2 kelompok sampel yaitu suplementasi zinc+jeruk dan kelompok zinc. Perhitungan sampel menggunakan perhitungan sampel untuk uji beda rata rata antar 2 kelompok independen dengan cara penomoran yaitu subjek yang mendapat nomor ganjil masuk kedalam kelompok intervensi dan subjek dengan nomor genap masuk dalam kelompok kontrol dan didapatkan besar sampel perkelompok 17 orang, sehingga jumlah sampel seluruhnya sebanyak 34 subjek. Sebelum dilakukan intervensi subjek diberi penjelasan tentang penelitian yang kan dilakukan dan diminta menandatangani informed consent/lembar persetujuan menjadi subjek penelitian.

\section{Variabel penelitian}

Variabel penelitian terdiri dari konsumsi jeruk+suplementasi zinc, dan kadar glukosa darah puasa. Kelompok Perlakuan adalah wanita DM tipe 2 yang mendapat suplementasi zinc sulfat $20 \mathrm{mg} /$ hari dalam bentuk sirup dan jeruk keprok 200 gram/hari yang terbagi dalam $2 \times$ konsumsi yaitu 1 buah jeruk keprok dan $10 \mathrm{mg}$ zinc pada saat selingan sore pukul 16.00 dan 1 buah jeruk keprok dan $10 \mathrm{mg}$ zinc sebelum tidur malam, sedangkan kelompok kontrol adalah wanita DM tipe 2 yang mendapat suplementasi zinc sulfat 20 $\mathrm{mg} /$ hari, dikonsumsi $2 \times 10 \mathrm{mg}$ pada pukul 16.00 dan malam sebelum tidur. Pemilihan jeruk keprok didasarkan pada kandungan asam organik (asam sitrat) yang terdapat pada jeruk keprok yang berfungsi untuk membantu penyerapan zinc dan jeruk keprok merupakan jenis jeruk yang paling banyak dikonsumsi masyarakat. Zinc yang digunakan berasal dari perusahaan suplemen zinc di Sidoarjo. Jeruk Keprok berasal dari Kebon Percontohan pada Balijestro (Balai Penelitian Tanaman Jeruk dan Buah Subtropika) Junrejo Batu Malang. Suplementasi dikonsumsi setiap hari selama 4 minggu. Pemeriksaan glukosa darah puasa dilakukan oleh petugas Balai Besar Laboratorium Kesehatan Surabaya. Pengambilan sampel darah untuk pemeriksaan kadar glukosa darah dilakukan sebanyak 2 $x$ selama penelitian yaitu pada awal sebelum dilakukan intervensi dan pada minggu ke 4 setelah intervensi selesai. Kadar glukosa darah puasa diukur menggunakan serum darah vena yang diambil sebanyak $1 \mathrm{ml}$ pada saat pagi hari sesudah puasa pada malam harinya minimal 8 jam. Dianalisis dengan alat automatic chemistry analizer tipe Prestige 24i menggunakan metode Tes UV enzimatik dengan heksokinase. Hasil pengukuran dinyatakan dalam $\mathrm{mg} / \mathrm{dl}$.

Variabel perancu yang dikendalikan adalah umur dan jenis obat (obat yang dikonsumsi jenisnya sama serta dicatat kepatuhannya). Variabel asupan dan aktifitas fisik dikendalikan dengan pemberian edukasi.

\section{Pengumpulan dan Pengolahan data}

Data karakteristik subjek meliputi : umur, pendidikan, pekerjaan, aktifitas fisik yang diperoleh melalui wawancara, data indeks massa tubuh dilakukan dengan mengukur berat badan (menggunakan timbangan injak digital dengan kapasitas $150 \mathrm{~kg}$ dan tingkat ketelitian $0,1 \mathrm{~kg}$ ), tinggi badan (menggunakan microtoa dengan ketelitian $0,1 \mathrm{~cm}$ ), serta asupan makanan menggunakan recall $3 \times 24$ jam dengan formulir food recall yaitu pada awal, pertengahan dan akhir penelitian yang terdiri dari 2 kali pada waktu hari kerja dan 1 kali pada waktu hari libur. Data asupan dianalisis menggunakan software nutrisurvey 2007. Tehnik analisis data meliputi analisis univariat untuk mengetahui gambaran deskriftif dari karakteristik masing masing variabel, analisis bivariat untuk melihat perbedaan kadar glukosa darah awal, akhir dan perubahan glukosa darah puasa pada 2 kelompok menggunakan uji independent $t$-test. Sedangkan analisis perubahan kadar glukosa darah puasa pada masing masing kelompok menggunakan uji Paired t-test. Data data tersebut diolah menggunakan software statistik.

ljin penelitian diperoleh dari Komisi Etik Penelitian Kesehatan Fakultas kedokteran Universitas Sebelas Maret Surakarta dengan nomer 427/UN27.6/KEPK/2019 serta dari Kantor Kesatuan Bangsa, Politik, dan Perlindungan Masyarakat Kota Surabaya dengan nomer 070/0445/436.8.5/2019.

\section{HASIL DAN PEMBAHASAN}

Berdasarkan kriteria yang ditentukan, diperoleh subjek penelitian sebanyak 34 orang. Selama penelitian berlangsung, ada 4 orang subjek penelitian yang drop out, terdiri dari 2 subjek pada kelompok perlakuan (jeruk) karena tidak melanjutkan konsumsi suplemen dan 2 orang dari kelompok kontrol (1 sakit dan dirawat di RS dan 1 tidak bisa datang pada waktu jadwal pengambilan darah post intervensi karena sakit).

Karakteristik subjek penelitian meliputi usia , tingkat pendidikan, pekerjaan, IMT dan akifitas fisik. Sebagian besar subjek penelitian berusia 40-60 tahun (67\%), pendidikan terbanyak SD dan SMA, pekerjaan Ibu Rumah Tangga (53\%) dengan aktifitas tergolong ringan $(80 \%)$ dan status gizi obesitas $(40 \%)$ seperti terlihat pada tabel 1. Usia subjek penelitian sebagian besar diatas 50 tahun (60\%), dimana resiko untuk terjadinya intoleransi glukosa darah meningkat seiring dengan meningkatnya usia ${ }^{18}$. Status gizi subjek penelitian berdasarkan IMT sebagian besar obesitas. Menurut Manna et al ${ }^{19}$, pada kondisi obesitas, kadar glukosa darah yang tinggi dan asam lemak bebas yang bersirkulasi dapat meningkatkan produksi ROS (Reactive Oxygen Species) yang terbukti mengurangi ekspresi gen insulin dan sekresi insulin. Aktifitas fisik pada subjek penelitian sebagian besar tergolong ringan (80\%). Menurut Ngaisah, terdapat hubungan antara kurangnya aktifitas olahraga sebagai faktor resiko diabetes melitus. Durasi olahraga adalah yang paling erat hubungannnya dengan kadar glukosa darah, diikuti oleh aspek rutinitas dan frekuensi olahraga ${ }^{20}$. 
Tabel 1. Distribusi karakteristik subjek antara kelompok zinc+jeruk dan zinc

\begin{tabular}{|c|c|c|c|c|c|c|}
\hline \multirow[b]{2}{*}{ Karakteristik } & \multicolumn{2}{|c|}{ Jeruk + Zinc $(n=15)$} & \multicolumn{2}{|c|}{ Zinc $(n=15)$} & \multicolumn{2}{|c|}{ Total } \\
\hline & Jumlah & $\%$ & Jumlah & $\%$ & Jumlah & $\%$ \\
\hline \multicolumn{7}{|l|}{ Usia } \\
\hline 43 - 60 tahun & 15 & 100 & 15 & 100 & 30 & 100 \\
\hline \multicolumn{7}{|l|}{ Pendidikan } \\
\hline Tidak sekolah & 1 & 7 & 2 & 14 & 3 & 10 \\
\hline SD & 5 & 33 & 5 & 33 & 10 & 33 \\
\hline SMP & 3 & 20 & 3 & 20 & 6 & 20 \\
\hline SMA & 5 & 33 & 5 & 33 & 10 & 33 \\
\hline PT & 1 & 7 & - & - & 1 & 3 \\
\hline \multicolumn{7}{|l|}{ Pekerjaan } \\
\hline Ibu Rumah Tangga & 7 & 47 & 9 & 60 & 16 & 53 \\
\hline Pedagang & 5 & 33 & 3 & 20 & 8 & 27 \\
\hline Penjahit & 1 & 7 & 2 & 13 & 3 & 10 \\
\hline Buruh & 2 & 13 & 1 & 7 & 3 & 10 \\
\hline Lain-lain & 0 & 0 & 0 & 0 & 0 & 0 \\
\hline \multicolumn{7}{|l|}{ Status Gizi (IMT) } \\
\hline Kurang & - & - & 1 & 7 & 1 & 3 \\
\hline Normal & 3 & 20 & 5 & 33 & 8 & 27 \\
\hline Overweight & 3 & 20 & 6 & 40 & 9 & 30 \\
\hline Obesitas & 9 & 60 & 3 & 20 & 12 & 40 \\
\hline \multicolumn{7}{|l|}{ Aktifitas Fisik } \\
\hline Ringan & 11 & 73 & 13 & 87 & 24 & 80 \\
\hline Sedang & 4 & 27 & 2 & 13 & 6 & 20 \\
\hline Berat & 0 & 0 & 0 & 0 & 0 & 0 \\
\hline
\end{tabular}

Aktifitas rendah dimungkinkan karena sebagian besar subjek adalah Ibu Rumah Tangga (53\%) dengan usia diatas 50 tahun (67\%), dimana aktifitas yang banyak dilakukan sehari-hari tergolong rendah, sedangkan aktifitas olahraga berupa senam pada klub Prolanis hanya dilakukan seminggu sekali.

Berdasarkan tabel 2 diketahui bahwa asupan zat gizi antar kedua kelompok juga tidak ada perbedaan kecuali pada asupan serat $(p=0,034)$, dimana perbedaan ini bisa mempengaruhi terhadap hasil variabel terikat yaitu glukosa darah puasa.

Pada tabel 3 terlihat bahwa kadar glukosa darah puasa mengalami penurunan setelah suplementasi baik pada kelompok jeruk + zinc maupun kelompok zinc. Hasil Uji Paired t-test untuk mengkaji perubahan kadar glukosa darah puasa menunjukkan bahwa perubahan kadar glukosa darah puasa pada kelompok jeruk+zinc tidak menunjukkan perubahan yang signifikan $(p=0,121)$, demikian juga pada kelompok zinc tidak menunjukkan perubahan yang signifikan $(p=0,095)$.

Berdasarkan hasil Uji independent t-test diketahui bahwa tidak terdapat perbedaan yang nyata pada perubahan kadar glukosa darah puasa antara subjek yang mendapat jeruk+zinc maupun subjek yang mendapat zinc saja $(p=0,555)$, sehingga dapat diambil kesimpulan bahwa penambahan jeruk 200 gram/hari pada suplementasi zinc kurang berpengaruh terhadap perubahan glukosa darah puasa pada pasien wanita DM tipe 2.

Tabel 2. Analisis perbedaan asupan zat gizi pada subjek penelitian

\begin{tabular}{lccc}
\hline \multirow{2}{*}{ Karakteristik } & \multicolumn{2}{c}{ Rerata } & \multirow{2}{*}{ P value } \\
\cline { 2 - 3 } & Jeruk+zinc(n=15) & Zinc (n=15) & \\
\hline Asupan energi ( kalori) & $1129,41 \pm 192,51$ & $1159,26 \pm 289,57$ & $0,742^{\mathrm{a}}$ \\
Asupan protein (gram) & $39,27 \pm 9,19$ & $38,60 \pm 11,69$ & $0,864^{\mathrm{a}}$ \\
Asupan Lemak (gram) & $45,09 \pm 15,22$ & $43,05 \pm 15,51$ & $0,719^{\mathrm{a}}$ \\
Asupan Karbohidrat (gram) & $147,15 \pm 33,39$ & $158,49 \pm 55,61$ & $0,504^{\mathrm{a}}$ \\
Asupan Serat (mg) & $7,2(4,5-15)$ & $5,4(2,7-9)$ & $0,033^{\mathrm{b} *}$ \\
Asupan Zinc (mg) & $4,15 \pm 1,78$ & $4,06 \pm 1,33$ & $0,842^{\mathrm{a}}$ \\
Asupan Fe (mg) & $8,6(3,2-19)$ & $5,9(1,8-16,4)$ & $0,744^{\mathrm{b}}$ \\
Asupan Kalsium (mg) & $232,75 \pm 105,62$ & $206,97 \pm 110,21$ & $0,518^{\mathrm{a}}$ \\
Asupan Vitamin C (mg) & $35(1-138,4)$ & $29,6(3,7-74,4)$ & $0,775^{\mathrm{b}}$ \\
\hline
\end{tabular}

${ }^{\mathrm{a}}$ Uji Independent t-test, ${ }^{\mathrm{b}}$ Uji Mann-Whitney, ${ }^{*}$ signifikan $(\mathrm{p}<0,05)$ 
Tabel 3. Rerata kadar glukosa darah puasa awal, akhir dan perubahan kadar glukosa darah puasa pada 2 kelompok.

\begin{tabular}{lccc}
\hline \multicolumn{1}{c}{ Variabel } & \multicolumn{2}{c}{ Kelompok } & \multirow{2}{*}{ P value $^{\mathbf{1}}$} \\
\cline { 2 - 3 } & \multicolumn{2}{c}{ Jeruk + Zinc (n=15) } & Zinc (n=15) \\
\hline Kadar glukosa darah puasa (mg/dl) : & $155,87 \pm 69,68$ & $140,93 \pm 42,27$ & 0,484 \\
Awal & $139,20 \pm 54,61$ & $131,13 \pm 45,75$ & 0,664 \\
Akhir & $-16,67 \pm 39,11$ & $-9,85 \pm 21,19$ & 0,555 \\
Perubahan glukosa darah puasa & 0,121 & 0,095 & \\
P value & & & \\
\hline
\end{tabular}

${ }^{1} \mathrm{Uji}$ Independent samples test, ${ }^{2}$ uji paired test, signifikan $(p<0,05)$

Pada kelompok suplementasi zinc, rerata penurunan kadar glukosa darah puasa $9,85 \mathrm{mg} / \mathrm{dl}$ dan tidak bermakna secara statistik. Suplementasi zinc pada pasien DM tipe 2 terbukti dapat mempertahankan kendali glikemik, meskipun kemungkinan juga tergantung pada status zinc individu ${ }^{21}$. Sistematik review dan meta-analisis yang dilakukan oleh Jayawardena et al menyatakan bahwa suplementasi zinc berpengaruh terhadap kontrol glikemik dan parameter lipid pada pasien diabetes. Terdapat 22 penelitian pada pasien DM Tipe 2 dengan durasi suplementasi 3 minggu sampai 5 tahun. Salah satunya menyebutkan bahwa dosis fisiologis suplementasi zinc ( $20 \mathrm{mg} /$ hari) selama 2 bulan menghasilkan efek yang menguntungkan pada status gizi dan status kekebalan ${ }^{22}$. Studi suplementasi zinc pada tikus winstar yang diinduksi streptozotozin menunjukkan bahwa pemberian suplementasi zinc sulfat selama 30 hari dengan 2 dosis yaitu $3 \mathrm{mg}$ per $\mathrm{kgBB}$ dan 5 $\mathrm{mg}$ per $\mathrm{kgBB}$ berpengaruh pada penurunan kadar glukosa darah dan peningkatan kadar SOD (Superoksida Dismutase)/enzim yang mampu menangkal radikal bebas dalam tubuh ${ }^{23}$. Penelitian Gunasekara menunjukkan bahwa pemberian zinc sulfat ( $22 \mathrm{mg} /$ hari) dan multivitamin/mineral selama 4 bulan pada pasien DM dewasa, secara bermakna dapat menurunkan glukosa darah puasa $0,33 \pm 0,21 \mathrm{mmol} / \mathrm{L}(p=0,05) 24$. Perbedaan hasil penelitian dimungkinkan karena durasi, subjek dan dosis yang berbeda sehingga hasil yang didapat berbeda. Penelitian yang telah dilakukan, sebagian besar berlangsung 3 sampai 6 bulan, sehingga penelitian jangka panjang memang perlu dilakukan mengingat karakteristik DM tipe 2 yang merupakan penyakit kronis.

Peran penting zinc antara lain dalam aksi insulin, pengatur stress oksidatif, proses peradangan dan apoptosis. Penelitian pada hewan menunjukkan potensi tentang manfaat ketersediaan zinc intraseluler pada sel $\beta$ pankreas dan jaringan target insulin 25 . Pengaruh zinc pada jalur sinyal insulin adalah zinc menyebabkan fosforilasi tirosin pada sub unit $\beta$ dari reseptor insulin dan penghambatan protein tyrosine phosphatase $1 B$ (PTP1B) yang difosforilasi reseptor insulin, sehingga meningkatkan fosforilasi reseptor. Akt (protein kinase $B$ ) yang diaktifkan oleh zinc bergantung pada enzim phosphatidylinositol 3-kinase (PI3K). Zinc juga menghambat glicogen sintase kinase 3 (GSK3), sama seperti insulin. Selain itu zinc juga berperan dalam transportasi glukosa karena merupakan bagian insulinreglukosated amino peptidase (IRAP) yaitu suatu molekul yang diperlukan untuk mempertahankan kadar normal glucose transporter (GLUT) ${ }^{26}$. Peran zinc dalam homeostasis insulin sudah jelas. Suplementasi zinc pada pasien DM tipe 2 dapat memperbaiki kontrol glikemik. Hal tersebut merupakan efek positif dari zinc serum yang adekuat terhadap kontrol glikemik (baik melalui diet atau suplemen) ${ }^{27}$.

Pada kelompok perlakuan (konsumsi jeruk dan suplementasi zinc), menghasilkan penurunan glukosa darah puasa yang lebih besar daripada kelompok kontrol (suplementasi zinc) yaitu $16,67 \mathrm{mg} / \mathrm{dl}$. Namun perubahan tersebut tidak signifikan secara statistik. Berdasarkan penelitian Mendoza et $a^{11}$, tentang efek fortifikasi makanan dengan komposisi $10 \mathrm{mg} \mathrm{Fe,10} \mathrm{mg}$ zinc sulfat, $100 \mathrm{mg}$ asam askorbat serta 1 gram asam sitrat bisa meningkatkan penyerapan zinc dan zat besi dari makanan. Pemilihan buah jeruk sebagai bahan makanan yang membantu penyerapan zinc pada pasien DM dengan mempertimbangkan kandungan zat gizi dan antioksidan. Hasil uji terhadap sampel buah jeruk yang digunakan untuk penelitian dilakukan di Universitas Brawijaya Malang yaitu di Laboratorium THP (Teknologi Hasil Pertanian) Fakultas Teknologi Pertanian. Hasilnya menunjukkan bahwa per 100 gram jeruk keprok batu mengandung energi 33 kalori, protein 0,51 gram, lemak 0,07 gram, Karbohidrat 7,6 gram, vitamin c 27,61 gram, kadar air 91,56 gram, total glukosa 4,95 gram, serat kasar 0,2 gram dan total asam 1,08 gram. Laporan hasil uji kadar asam sitrat pada jeruk keprok yang dilakukan di laboratorium Baristand Industri Surabaya menunjukan kandungan asam sitrat pada jeruk keprok yang digunakan pada penelitian ini adalah $0,53 \%$. Jeruk merupakan sumber alami asam sitrat ${ }^{12}$. Asam sitrat yang merupakan asam organik (ion berberat molekul rendah) mempunyai dampak positif terhadap penyerapan zinc serta telah dipakai untuk suplemen ${ }^{28}$. Selain itu juga mengandung zat bioaktif seperti fenolik (flavanon, flavones, flavonol dan asam fenolik). Flavonon pada jeruk adalah hisperedin, eriocitrin naringin ${ }^{13}$. Hisperedin terbukti dapat menurunkan kadar glukosa darah, serta meningkatkan plasma insulin dan glikogen pada tikus yang diinduksi streptozotozin ${ }^{14}$. Pektin pada jeruk dapat mempengaruhi kadar glukosa darah puasa, mengurangi resistensi insulin, meningkatkan toleransi glukosa dan kadar glikogen hati pada tikus $\mathrm{DM}^{15}$.

Berdasarkan analisis asupan makanan pada subjek penelitian diketahui bahwa asupan zat gizi energi, karbohidrat, protein, lemak, zinc, zat besi, kalsium dan vitamin c pada kedua kelompok tidak berbeda secara statistik. Perbedaan asupan terletak pada asupan serat. Meskipun secara umum asupan serat dari subjek penelitian tergolong rendah, tetapi pada kelompok jeruk+zinc, rerata asupan seratnya lebih tinggi karena pada kelompok jeruk+zinc terdapat subjek yang mempunyai kebiasaan mengkonsumsi makanan tinggi 
serat setiap hari (2 kali per hari) yaitu buah seperti apel, pepaya dan jambu. Perbedaan asupan serat ini menyebabkan penurunan kadar glukosa darah puasa pada kelompok jeruk+zinc lebih besar dibandingkan dengan kelompok zinc. Penurunan glukosa darah puasa pada kelompok jeruk+zinc yaitu $16,67 \mathrm{mg} / \mathrm{dl}$ sedangkan pada kelompok zinc $9,85 \mathrm{mg} / \mathrm{dl}$. Namun penurunan kadar glukosa darah puasa tersebut secara statistik tidak berbeda nyata pada kedua kelompok.

Asupan vitamin C pada subjek penelitian kurang dari kebutuhan baik pada kelompok jeruk+zinc maupun pada kelompok zinc. Menurut Dakhale et al ${ }^{29}$, Vitamin C merupakan antioksidan yang berperan penting dalam melindungi kerusakan radikal bebas. Vitamin C secara struktural mirip glukosa dan dapat menggantikannya dalam banyak reaksi kimia sehingga efektif untuk pencegahan glikosilasi non enzimatik pada pasien DM. Vitamin C sebagai antioksidan memiliki efek menguntungkan pada fungsi sel $\beta$ yaitu mempengaruhi sensitifitas insulin dan menurunkan kadar glukosa darah melalui penurunan toksisitas glukosa dan pencegahan penurunan massa sel $\beta$.

Penelitian tentang suplementasi zinc yang dikombinasikan dengan jeruk belum ada, sehingga untuk acuan hasil penelitian berdasarkan penelitian tentangsuplementasi zinc secara tunggal yaitu berdasarkan sistematic review dan meta-analisis yang dilakukan oleh Jayawerdana et al terhadap 12 penelitian tentang suplementasi zinc pada pasien DM tipe 2 dengan waktu intervensi 3 minggu sampai 4 bulan dengan dosis pemberian suplementasi zinc $10-660$ $\mathrm{mg} /$ hari menghasilkan penurunan pada kadar glukosa darah puasa sebesar $18,13 \mathrm{mg} / \mathrm{dl}^{22}$.

Penambahan konsumsi jeruk 200 gr/hari pada suplementasi zinc tidak berpengaruh terhadap glukosa darah puasa wanita DM tipe 2 dimungkinkan karena perbedaan penyerapan zinc pada masing masing individu subjek penelitian, dimana penyerapan zinc tersebut dipengaruhi oleh banyak faktor antara lain asupan beberapa zat gizi yang membantu atau menghambat penyerapan zinc. Menurut Lonnerdal, defisiensi zinc banyak terjadi di negara berkembang. Hal tersebut disebabkan karena asupan zinc yang tidak adekuat, serta faktor penyerapan zinc. Fitat pada

\section{REFERENS}

1. IDF. Eighth edition 2017. International Diabetes Federation. IDF Diabetes Atlas, 8th edn. Brussels, Belgium: International Diabetes Federation, 2017.

http://www.diabetesatlas.org (2017). doi:http://dx.doi. org/10.1016/S01406736(16)31679-8.

2. Kemenkes RI. Riskesdas 2018. Development 1220 (2018).

3. Chan, M. Global report on diabetes. World Heal. Organ. 58, 1-88 (2014).

4. Care, M. Standards of Medical Care in Diabetes-2008. Diabetes Care 31, S12-S54 (2008).

5. Ranasinghe, P., Pigera, S., Galappatthy, P., Katulanda, P. \& Constantine, G. R. Zinc and diabetes mellitus: Understanding molecular makanan pokok seperti sereal, jagung dan beras mempunyai efek negatif yang besar terhadap penyerapan zinc. Zat besi berpengaruh negatif pada penyerapan zinc jika diberikan dalam bentuk suplemen tetapi tidak berefek ketika terdapat pada makanan sebagai fortifikan, sedangkan makanan memiliki efek positif pada penyerapan zinc adalah protein, terutama protein hewani ${ }^{28}$. Berdasarkan data asupan makanan diketahui bahwa asupan zinc pada subjek penelitian kurang dari kebutuhan baik pada kelompok jeruk+zinc (4,15 mg zinc/hari) maupun pada kelompok zinc $(4,06$ $\mathrm{mg}$ zinc/hari). Kecukupan zinc berdasarkan AKG pada wanita usia $30-64$ tahun adalah $10 \mathrm{mg} /$ hari. Demikian juga dengan asupan protein hewani yang memiliki efek positif pada penyerapan zinc. Subjek penelitian lebih banyak mengkonsumsi sumber protein nabati berupa tahu, tempe dan kacang-kacangan dibandingkan dengan sumber protein hewani.

Keterbatasan pada penelitian ini adalah waktu intervensi hanya 4 minggu sehingga belum dapat menjamin perubahan metabolisme zinc yang berkaitan dengan kontrol glukosa darah sehingga perubahan yang ada menyebabkan intervensi suplementasi zinc dan jeruk ini tidak significan secara statistik. Meskipun terdapat penelitian dengan waktu intervensi 3 minggu, tetapi rata rata penelitian yang telah dilakukan untuk suplementasi zinc tunggal adalah $3-6$ bulan. Sehingga intervensi penelitian selanjutnya dapat dilakukan minimal dengan waktu intervensi 3 bulan.

\section{KESIMPULAN}

Terdapat penurunan glukosa darah puasa wanita Diabetes Melitus tipe 2 yang mendapat suplementasi zinc (20 mg/hari) dan jeruk $200 \mathrm{~g} / \mathrm{hari}$ selama 4 minggu namun perubahannya tidak signifikan. Perlunya dilakukan penelitian lanjut dengan waktu intervensi yang lebih lama.

\section{ACKNOWLEDGEMENT}

Penulis menyampaikan terima kasih kepada semua pihak yang telah membantu proses penelitian ini

mechanisms and clinical implications. DARU, J. Pharm. Sci. 23, 1-13 (2015).

6. Giacconi, R. et al. Implications of impaired zinc homeostasis in diabetic cardiomyopathy and nephropathy. BioFactors 43, 770-784 (2017).

7. Fernández-Cao, J. C. et al. Dietary zinc intake and whole blood zinc concentration in subjects with type 2 diabetes versus healthy subjects: A systematic review, meta-analysis and metaregression. J. Trace Elem. Med. Biol. 49, 241251 (2018)

8. Luo, Y. Y. et al. Relationship between serum zinc level and microvascular complications in patients with type 2 diabetes. Chin. Med. J. (Engl). 128, 3276-3282 (2015).

9. Wu, H., Wang, L. \& Introduction, I. and „TiO 2 $\ldots \mathrm{n}, \mathrm{n} 51-4 \ldots .107,8221-8228$ (1997).

10. Silva, E. O. \& Bracarense, A. P. F. R. L. Phytic Acid: From Antinutritional to Multiple 
Protection Factor of Organic Systems. J. Food Sci. 81, R1357-R1362 (2016).

11. C., M., J.M., P., K.H., B. \& B., L. Effect of a micronutrient fortificant mixture and 2 amounts of calcium on iron and zinc absorption from a processed food supplement. Am. J. Clin. Nutr. 79, 244-250 (2004).

12. Yilmaz, E., Batislam, E., Basar, M., Tuglu, D. \& Erguder, I. Citrate Levels in Fresh Tomato Juice: A Possible Dietary Alternative to Traditional Citrate Supplementation in Stone-Forming Patients. Urology 71, 379-383 (2008).

13. Aruoma, O. I. et al. Functional benefits of citrus fruits in the management of diabetes. Prev. Med. (Baltim). 54, S12-S16 (2012).

14. Jayaraman, R., Subramani, S., Sheik Abdullah, S. H. \& Udaiyar, M. Antihyperglycemic effect of hesperetin, a citrus flavonoid, extenuates hyperglycemia and exploring the potential role in antioxidant and antihyperlidemic in streptozotocin-induced diabetic rats. Biomed. Pharmacother. 97, 98-106 (2018).

15. Liu, Y., Dong, M., Yang, Z. \& Pan, S. Anti-diabetic effect of citrus pectin in diabetic rats and potential mechanism via PI3K/Akt signaling pathway. Int. J. Biol. Macromol. 89, 484-488 (2016).

16. JR, H., JM, B. \& LK, J. Adaptation in human zinc absorption as influenced by dietary zinc and bioavailability. Am. J. Clin. Nutr. 87, 1336-1345 (2008).

17. Tran, C. D., Miller, L. V., Krebs, N. F., Lei, S. \& Hambidge, K. M. Zinc absorption as a function of the dose of zinc sulfate in aqueous solution. Am. J. Clin. Nutr. 80, 1570-1573 (2004).

18. PERKENI. Pengolahan dan Pencegahan Diabetes Melitus Tipe 2 Di Indonesia 2015. (2015). doi:10.1017/CBO9781107415324.004

19. Manna, P. \& Jain, S. K. Obesity, Oxidative Stress, Adipose Tissue Dysfunction, and the Associated Health Risks: Causes and Therapeutic Strategies. Metab. Syndr. Relat. Disord. 13, 423-444 (2015).

20. RADEN RORO DEWI NGAISYAH. Hubungan
Asupan Kromium Dengan Tingkat Gula Darah Pada Anggota Persadia Samarinda Tahun 2010 Tesis Raden Roro Dewi Ngaisyah Fakultas Kesehatan Masyarakat Depok. Fak. Kesehat. Masy. Progr. Stud. Ilmu Kesehat. Masy. (2010).

21. Accepted article. J. Subst. Abuse Treat. (2003). doi:10.1016/s0740-5472(96)90021-5

22. Jayawardena, R. et al. Effects of zinc supplementation on diabetes mellitus: A systematic review and meta-analysis. Diabetol. Metab. Syndr. 4, (2012).

23. Kartika, N., Rachmawati, B. \& Johan, A PENGARUH PEMBERIAN Zn TERHADAP KADAR GLUKOSA DARAH DAN KADAR SUPEROKSIDA DISMUTASE PADA TIKUS WISTAR YANG DIINDUKSI STREPTOZOTOCIN. J. Kesehat. 9, 61 (2017).

24. Gunasekara, P., Hettiarachchi, M., Liyanage, C. \& Lekamwasam, S. Effects of zinc and multimineral vitamin supplementation on glycemic and lipid control in adult diabetes. Diabetes, Metab. Syndr. Obes. Targets Ther. 4, 53-60 (2011).

25. Pirogov, V. A., Reizin, E. S. \& Tartakovskii, B. D. Matching Layers for Electroacoustic Receiving Transducers. Sov Phys Acoust 19, 478-481 (1974).

26. Jansen, J., Karges, W. \& Rink, L. Zinc and diabetes - clinical links and molecular mechanisms. J. Nutr. Biochem. 20, 399-417 (2009).

27. Pires, L. V., de Carvalho, G. B., Brandão-Lima, P. N., Maia, C. S. C. \& Barbosa, K. B. F. Zinc's role in the glycemic control of patients with type 2 diabetes: a systematic review. BioMetals 30, 151-162 (2017).

28. Lo, B. Zinc and Health : Current Status and Future Directions Dietary Factors Influencing Zinc Absorption 1. 1378-1383 (2000).

29. Dakhale, G. N., Chaudhari, H. V \& Shrivastava, $M$. Supplementation of Vitamin C Reduces Blood Glucose and Improves Glycosylated Hemoglobin in Type 2 Diabetes Mellitus : A Randomized, Double-Blind Study. 2011, (2011). 